\title{
EFFECTS OF DIFFERENT ORGANIC FERTILISER LEVELS ON THE GROWTH OF COFFEE SEEDLINGS IN THE NURSERY
}

\section{BY}

\section{YVETTE. T. MUSAGOMBA}

A thesis submitted in partial fulfilment of the requirements for the degree of

\author{
Bachelor of Science (Honours) \\ Degree in Agronomy \\ Midlands State University
}

Faculty of Natural Resources Management and Agriculture

Department of Agronomy

November 2017 


\section{DECLERATION}

I hereby declare that this dissertation is original with my own efforts to do the investigations and such work has not been presented elsewhere for any degree or scholarly work. All additional sources of information used in this dissertation have been acknowledged by means of referencing. MUSAGOMBA.YVETTE. T

STUDENT REG No. R142239E

Signature

Date

\section{CERTIFICATION OF THESIS WORK}

I, the undersigned, certify that Yvette. Musagomba, a candidate for the Bachelor of Science Honours Degree has presented this dissertation with the tittle:

EFFECTS OF DIFFERENT FERTLISERS LEVELS ON THE GROWTH OF COFFEE SEEDLINGS.

SUPERVISOR: DOC.V. MAKUVARO

SIGNITURE: 


\section{DEDICATION}

To my parents Mr. C and Mrs. L Musagomba and my beloved brother Chenjerai and sisters Millicent and Olivia Musagomba. 


\section{ACKNOWLEDGEMENTS}

I am thankful to Coffee Research Institute for giving me the chance to do my research project at the institution and the provision of man power and ideas. All thanks to Mr S. Tarusenga, Mr C. Mahoya, Mr P. Chidoko, Mr N Rahenye for their support and all corrections they made during the course of the project. Also great thanks to the Agronomy department for their assistance in laying out the experiment and data collection.

My heartfelt gratitude goes to my academic supervisor Doctor V. Makuvaro for her unceasing efforts and advise throughout the research which resulted in the completion of this thesis.

Lots of thanks to my family and friends for their moral and financial support throughout the period 1 was doing this project. 


\section{LIST OF ACRONYMS}

$\begin{array}{ll}\text { CM } & \text { Cattle Manure } \\ \text { CORI } & \text { Coffee Research Institute } \\ \text { CRD } & \text { Completely Randomized Design } \\ \text { GM } & \text { Goat Manure } \\ \text { ICO } & \text { International Coffee Organization } \\ \text { PM } & \text { Poultry Manure } \\ \text { SM } & \text { Sheep Manure }\end{array}$




\section{Table of contents}

\section{Contents}

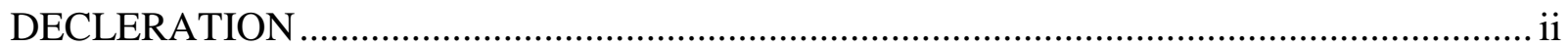

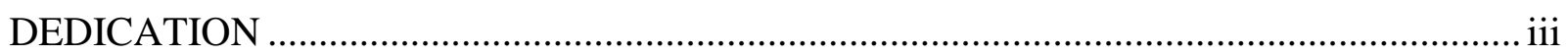

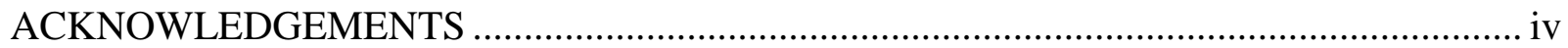

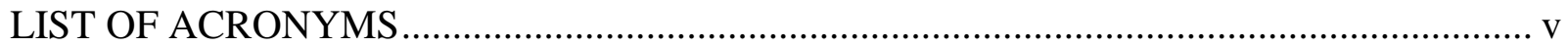

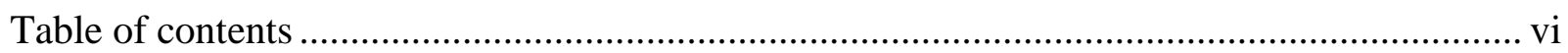

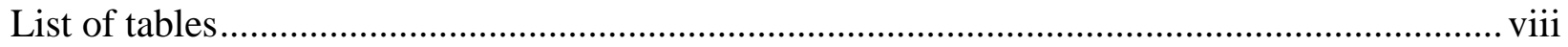

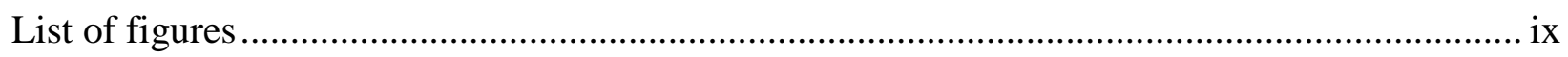

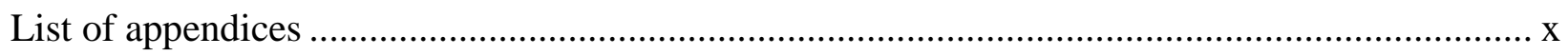

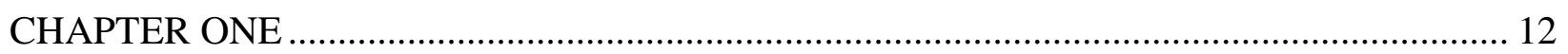

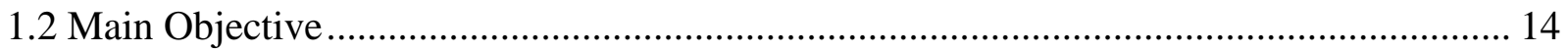

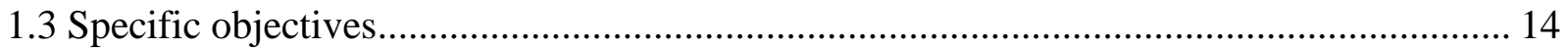

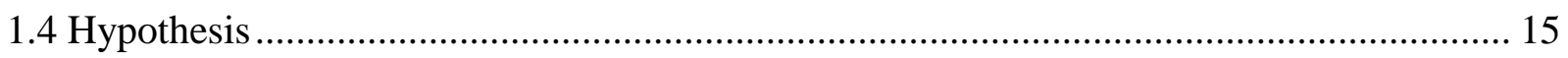

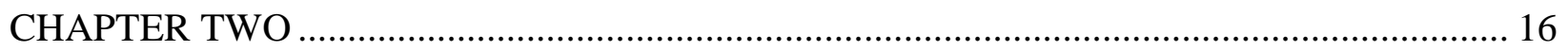

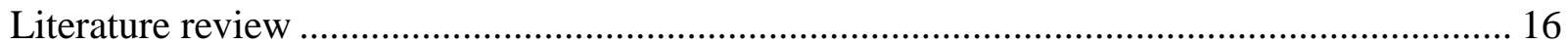

2.1 Importance of coffee to Zimbabwe ................................................................... 16

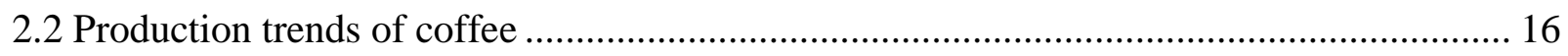

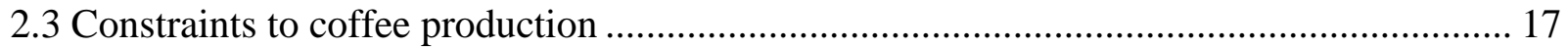

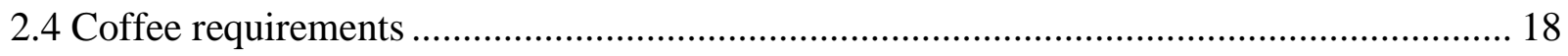

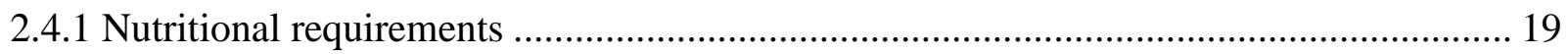

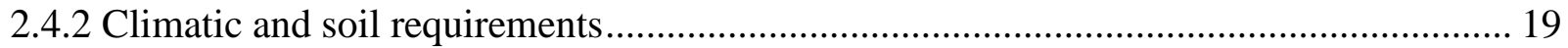

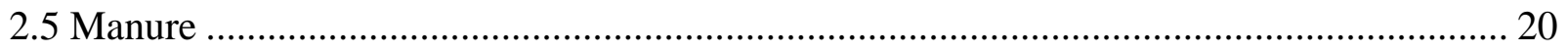

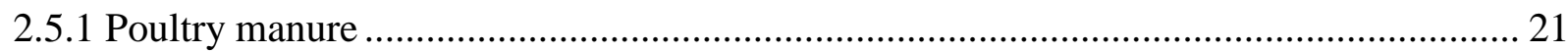

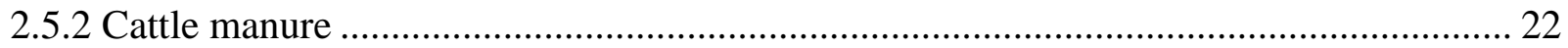

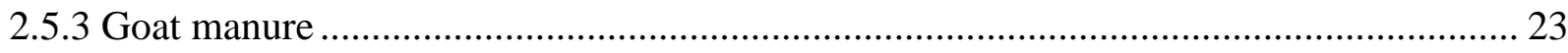

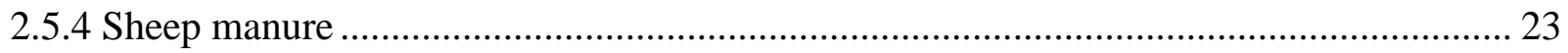

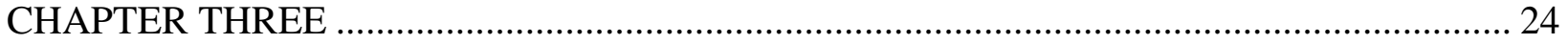

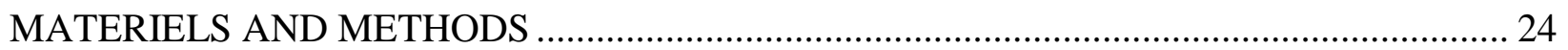

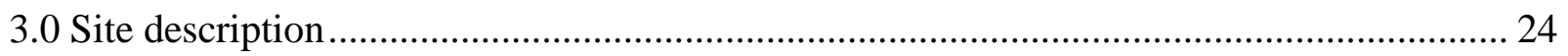

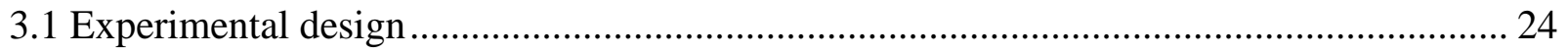




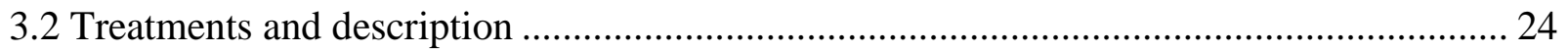

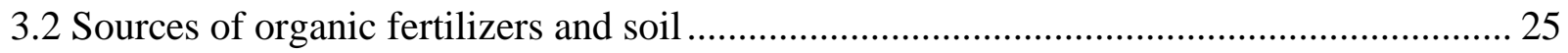

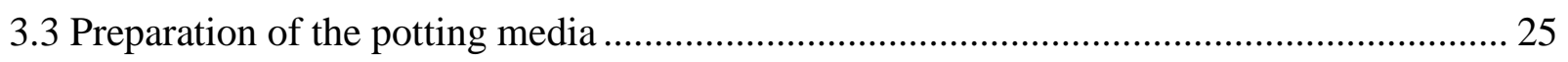

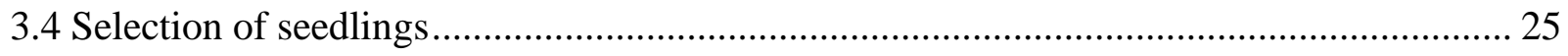

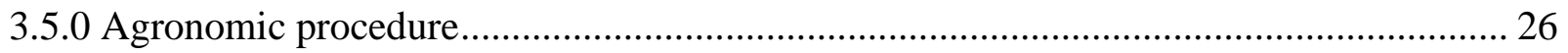

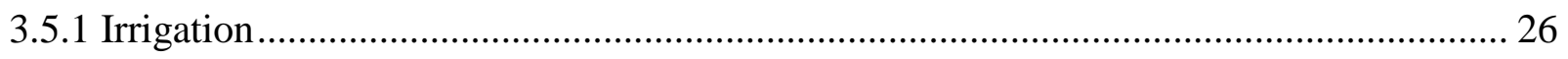

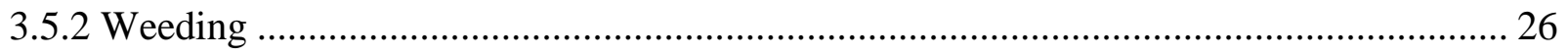

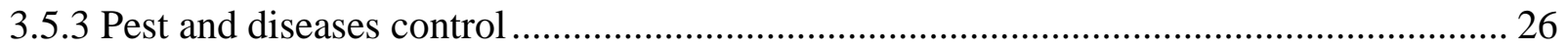

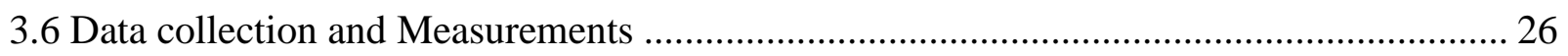

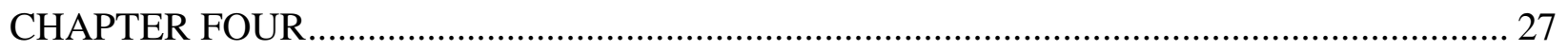

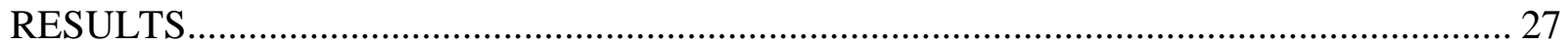

4.1 Effects of different fertilizer levels on coffee seedlings ................................................ 27

4.3 Effects of different fertilizer levels on number of leaves in coffee seedlings ..................... 28

4.4 Effects of different fertilizer levels on number of leaves in coffee seedlings ..................... 29

4.5 Effects of different fertilizer levels on dry matter accumulation in coffee seedlings ......... 30

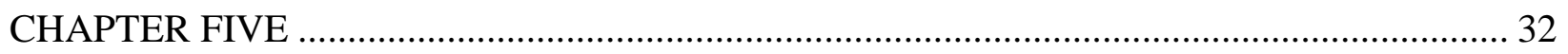

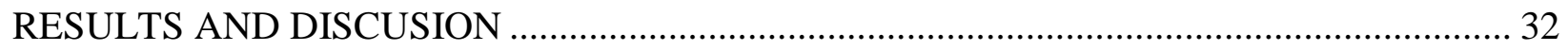

5.1 Effects of different fertilizer application levels on stem length of coffee seedlings ........... 32

5.2 Effects of different fertilizer application levels on stem girth of coffee seedlings ............. 32

5.3 Effects of different fertilizer application levels on number of leaves of coffee seedlings.. 33

5.4 Effects of different fertilizer application levels on root length of coffee seedlings ............ 33

5.5 Effects of different fertilizer application levels on dry matter accumulation in coffee

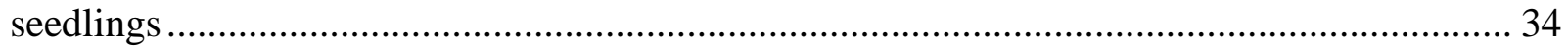

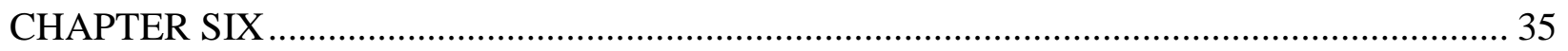

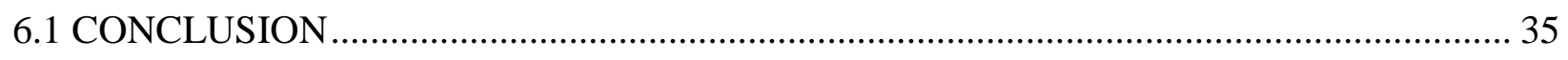

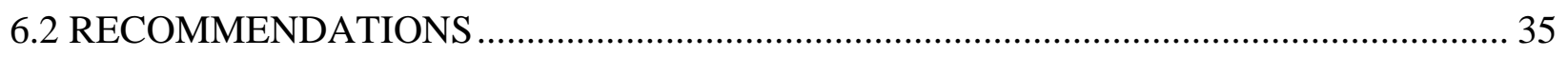

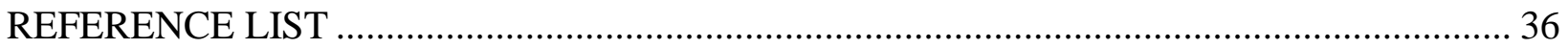

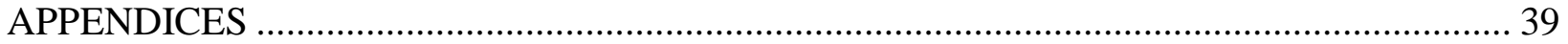


List of tables

Table 3.2 Treatments and description 


\section{List of figures}

Figure 4.1 Effects of different fertilizer levels on stem height of coffee seedlings

Figure 4.2 Effects of different fertilizer levels on stem girth of coffee seedlings

Figure 4.3 Effect of different fertilizer levels on number of leaves in coffee seedlings

Figure 4.4 Effects of different fertilizer levels on root length of coffee seedlings

Figure 4.5 Effects of different fertilizer levels on dry matter accumulation in coffee seedlings 


\section{List of appendices}

Analysis of variance on stem height of coffee seedlings

Analysis of variance on stem girth coffee seedlings

Analysis of variance on number of leaves in coffee seedlings

Analysis of variance on root length on coffee seedlings

Analysis of variance on dry matter accumulation in coffee seedlings 


\section{ABSTRACT}

Coffee is a major foreign currency earner in Zimbabwe and also a source of employment to a large population in Zimbabwe. The coffee industry is facing challenges which are resulting in decrease in production. One of the reasons for this decline in production is lack of funds to maintain the coffee farms and re-plant coffee plants which are more productive for the old plants are now less productive. Also there is need to establishing new plants in-order to expand the area under cultivation. This gave rise to need of researching on the ways of overcoming the problem of lack of money to buy fertilizers needed for in the raising of coffee seedlings. Hence a research was done at Coffee Research Institute (CORI) in Chipinge in 2016 to investigate on the different fertilizer types (poultry, cattle, goat, sheep) at different levels $(100 \mathrm{~g}, 250 \mathrm{~g}, 500 \mathrm{~g}$ per planting pot $12 \mathrm{~cm} \times 25 \mathrm{~cm}$ ). The experiment was laid in a $3 \times 4$ Factorial arrangement in a Completely Randomized Design (CRD). The variety used in the research was Catmor 129. The results obtained in the experiment indicated that there was interaction $p<0.05$ between level of application and the type of organic fertilizer used. An increase in application level of cattle, goat and sheep manure resulted in increased stem height however an increase in poultry manure from $250 \mathrm{~g}$ to $500 \mathrm{~g}$ did not result in increased stem height. An increase in level of application of all the fertilizer types poultry, cattle, goat and sheep manure resulted in an increase in stem girth, number of leaves, root length and dry matter accumulation in the seedlings. The fertilizers under investigation were compared with the standard thus the current fertilizer compound S 6-17-6 (NPK) and the control which was untreated soil. Compound S outperformed the organic fertilizers in stem height. Also at $100 \mathrm{~g}$ of all organic fertilizers compound S performed better in all growth parameters. At all application levels all the organic fertilizers performed better than the control (untreated soil). Basing on the research findings, farmers who cannot afford synthetic fertilizers can use poultry manure at an application rate of $500 \mathrm{~g}$ per planting pot. 


\section{CHAPTER ONE}

\subsection{Introduction}

Coffee (Coffea arabica) is a crop of great importance to Zimbabwe. Coffee is one of the major foreign currency earner in Zimbabwe with over $98 \%$ of the total produce being exported (Schumann, 2014). Coffee can be ranked second after oil in its value as a worldwide product (Schumann, 2014; Ameson 2000). In Zimbabwe, coffee is produced mainly in Chipinge, sMutare, Chimanimani and Mutasa districts, in the northern parts of the country in Harare, Mhangura and Guruve districts (CORI, 2010).

Coffee is a perennial crop which is mono-cropped in many parts of Zimbabwe. It can also be intercropped with bananas to provide shade. Coffee production starts with the selection and raising of seedlings in the nursery. The successful growth and development of coffee trees and their subsequent productivity is highly dependent on the initial establishment of the seedlings. It is at this time when crucial root development takes place, and if impeded in anyway, the future trees will manifest weakness throughout their life. The situation becomes very critical when the tap root hits a hard pan in the first 3-4 years of establishment. Trees start to die randomly from about the fourth year onwards. Coffee trees will be out of production in two to three years after onset of the first production cycle. Hence when crop expectation for the following season gets low there is need to rejuvenate and this is done during the warmer times thus in September and not later than October. Rejuvenation can be done after six crops in cool areas and after four crops in warmer areas. When production of the trees goes down even after rejuvenation then consider replanting. Harvesting can be done for three cycles with each cycle lasting for 5 years of less after the third cycles production will be low. Most small holder farmers who are engaged in coffee farming can leave the coffee trees to grow without maintenance and only give them an eye when it is time for harvesting. This results in production of poor quality coffee and also it shortens the span of the tree.

Healthy seedling growth is supported by adequate supply of water and nutrients in the soil medium. Some recommendations for nursery establishment are mixing virgin forest soil with compound $\mathrm{S}$ 6-17-6 (NPK) fertilizer and phosphate rock. However, small holder farmers do not afford fertilizers. Therefore, due to high costs of inorganic fertilizers in Zimbabwe there is need to come 
up with effective alternative ways in coffee seedling production in-order to produce healthy and quality coffee seedlings at low cost.

Need for renewable, locally available and cheap sources of nutrients for plants, has become a necessity in order to cut production costs for smaller holder farmers. Prolonged use of inorganic fertilizers can also lead to adverse effects on soil properties such as structure, water holding capacity, $\mathrm{pH}$, and lowered microbial activity which does not support sustainable agricultural production. Research works show that organic amendments can be beneficial in supporting soil organisms and due to slow release of nutrients this will slow down the rate at which they are leached. Organic soil management can sustain coffee growth when water supply is low by improving soil moisture conservation and water use efficiency (Chemura et al., 2013).

Also use of inorganic fertilizers can lead to depletion of other trace elements needed by the plant and also destruction of soil micro and macro organisms which are beneficial to the seedlings hence use of organic fertilizers will help overcome the negative effects of using inorganic fertilizer.

Small holder farmers need to add nutrients to seedlings in-order to attain healthy and quality seedlings with high survival rates when transplanted into the field, without them having to face high production costs. There-fore there is need to use affordable and available sources of nutrients. Virgin forest soils are recommended for seedling production because they are free from diseases and they also contain some nutrients. Due to de-forestation, virgin fertile soils are now scarce hence there is need to use top soil in conjunction with organic manures in order to obtain quality seedlings. Also use of organic fertilizers has proven to be environmentally friendly. Growth is high under low irrigation to plants treated with organic manure than those with inorganic fertilizers (Chemura et al., 2013) hence use of organic manures will also be advantageous due to high soil moisture retention and utilization in respect to changes in weather conditions.

After conducting a few visits to the small holder coffee producers in Chipinge, Mafumise, Honde valley most of the farmers do not replant their coffee due to lack of money to purchase seedlings. Also a high cost of producing the seedlings on farm due to lack of money to buy certified seeds and fertilisers. How-ever Coffee Research Institute (CORI) has been raising seedlings for farmers, this will only benefit farmers nearby the research station. There is also a drawback of disease spread, back then when the coffee industry was still producing at full capacity seeds were certified from the Eastern Highveld how-ever due to mismanagement these areas are now infested by 
diseases like fussarium wilt, coffee leaf rust, cercospora leaf spot and coffee berry disease hence there is need for farmers to produce seed and seedlings on farm to reduce rate of disease dissemination. Also seedlings are needed for gap filling and replanting to replace trees which would have been affected by diseases like black soot mould. Since coffee trees are less productive when old and are more prone to diseases there is need to renew and also replace affect crops. Studies done showed that poultry manure is more promising in coffee seedling production.

Use of organic fertilisers to add nutrients to the soil is a practice which was done from early days but at current due to popularity of synthetic and chemical fertilizers farmers are shunning organic manures which is resulting in them facing challenges like high production cost. This is so because of the high cost of the fertilisers. Also most smallholder farmers cannot afford them which is resulting in low production in the coffee industry and other sectors. Despite organic manure having been used, there is need to know the levels of application at certain stages of a plant's growth stage and also to know the type of organic manure which suit certain crop types. For instant too much of phosphorous will result in it binding up with other elements making them unavailable to plants. This research was done to find out the level of application and the type of manure which provides nutrients and conditions more favourable for optimum growth of coffee seedlings. Growth medium has been found to be the most critical factor determining seedling quality in the nursery and acting as a reservoir of nutrients, moisture and oxygen supply to the growing plant (Baiyeri and Mbah 20006). Nursery rooting media mixtures play a key role in improving soil chemical properties and thereby improving the rate of seed germination and seedling growth and penetrating capacity of the root and sufficient nutrient supply from the media which will ensure luxurious seedlings growth (Neelam and Ishtiaq, 2001).

\subsection{Main Objective}

To determine the level of organic fertilizer (poultry, cattle, goat and sheep) on growth of coffee seedlings in the nursery.

\subsection{Specific objectives}

1.3.1 To determine the effect of different organic fertilisers levels $(100 \mathrm{~g}, 250 \mathrm{~g}$ and $500 \mathrm{~g} / \mathrm{pot})$ on growth parameters (height, girth, number of leaves, root length, dry matter accumulation) of coffee seedlings. 


\subsection{Hypothesis}

1.4.1 Different levels of organic fertilisers have a significant effect on growth (height, girth, number of leaves, root length, dry matter accumulation) of coffee seedlings. 


\section{CHAPTER TWO}

\section{Literature review}

\subsection{Importance of coffee to Zimbabwe}

Coffee cultivation is thought to have originated from Ethiopia uplands in the $14^{\text {th }}$ century (Kumar et al,2009). The two most grown coffee species are coffea arabica and coffea canephora . Arabica coffee produces Arabica beans which accounts for $80 \%$ of the coffee drunk by people. Coffee was introduced in Zimbabwe around 1894 by white settlers, coffee production is done in the eastern highlands of the country which include Chipinge, Chimanimani, Mutare and Mutasa districts and in the northern side of the country coffee is cultivated in Hurungwe, Guruve and Makonde districts (Chidoko 2013; Chemura et al 2014). Coffee sector in Zimbabwe consists of both large and small holder sector, the greatest percentage being the small holder farmers.

World coffee consumption has progressively increased by a rate of 1,9\% over the past half a century, from 57.9 million bags in 1964 to 142 million bags in 2012 (International Coffee Organization, 2014) this in-turn results in demand for coffee and poses positive impacts on coffee producing countries like Zimbabwe. The argument in the increase in the consumption of coffee worldwide was also reinforced by Osorio, (2010) who emphasized that consumption of coffee has risen from 104, 7 million bags in 2000 to 132 million bags in 2009. Osorio, further ascertained that from 2000 to 2009, coffee exports were at the peak in 2008 amounting US \$15, 3 billion with the lowest being 2002 which accumulates US \$5, 2 billion. Aside from benefits in form of foreign currency the coffee industry plays an important role as far as employment is concerned. The coffee industries used to employ many people from Zimbabwe and from other countries like Malawi. According to (International Coffee Organization 2013) the coffee industry used to employ over 20,000 people before year ending 2000. Coffee production also contributes in improving livelihoods of coffee farmers.

\subsection{Production trends of coffee}

Brazil is the world largest producer of coffee with an average annual production of 35, 7 million bags from 1989/90 to 2012/2013 (International Coffee Organization, 2014). The leading world producer of coffee is Brazil according to the 2008 and 2009 season with an estimation of 36, 8\% of the total coffee production worldwide, according to Osorio, (2010). Vietnam was the second producer worldwide, Indonesia being the third and Ethiopia being the African dominating producer 
of coffee holding the forth position according to the data by Osorio, (2010). Major foreign currency is earned by coffee with over $98 \%$ of the total production being exported also oil is the only commodity which out competes coffee (Schumann, 2014). Consumption of coffee has increased by $1.9 \%$ over the past half century, which was recorded as 57.9 million bags in 1964 to 142 million bags in 2012 by International Coffee Organisation (International Coffee Organisation ,2014).

About $12 \%$ of the global supply and at most $11 \%$ global export of coffee was accounted for by African coffee producers during the 2009 to 2010 season. African contributions during the 2009 to 2010 season to the global market were approximately equal to Indonesia's, which is the third largest coffee producer world-wide (Commodity market brief journal of 12 July 2010).

\subsection{Constraints to coffee production}

There are a number of economic constraints for the production of coffee in Zimbabwe and other developing countries that produce coffee, for both large-scale and smallholder farmers. The major factors towards the production of coffee in Zimbabwe include lack of funds by farmers to reestablish their crop which was destroyed during the land reform programme of 2001 and also crops damaged due to harsh weather conditions during the 2004-2005 season .There is also need to do out with the old coffee trees and replant new healthy and more productive plants but due to lack of funds to produce seedlings and start replanting farmers are still holding on the old plants which are producing little and low quality coffee berries. Also the lack of supplementary irrigation infrastructure in dry coffee producing regions. In small scale coffee producing farmers, there is a lack of medium-to-long term financing programs for plantation crops. This leads to marginalization of smallholder coffee farmers, poor standard managerial and technical capacities. It also results in poor linkages between the government research services due to inadequate funding as well as poor access to production inputs such as fertilisers, pesticides for the control of insect pests and diseases (Kimani et al, 2002; Flood, N.D; Silva et al, 2006, Masasi, 2015).

The farmers sell their coffee produce to the middlemen who give them lower prices than those of international market thereby being isolated from the markets (Kimani et al, 2002). Another limiting constrain that affects coffee farmers is the world coffee prices that are volatile and highly fluctuating (Kimani et al, 2002). Coffee Arabica is highly sensitive to extreme weather conditions that include droughts, frost action which reduces the quality, volume and the value of the crop (Worku and Astatkie, 2009); Flood, N.D; Anon, 2012) and this makes it problematic for farmers 
to follow the appropriate agronomic practices to successfully and effectively manage coffee insect pests, diseases and nutrition at full capacity. The coffee industry lacks an independent board which controls the production of coffee and its marketing.

Zimbabwean coffee was famous for its super high quality product and during the 1990s it produced some of the best coffee in the world alongside South America and Kenya. How-ever at present Zimbabwean coffee industry has fallen down in terms of quantity and quality mills have been abandoned due to under production. Production from Zimbabwe has in recent years gone down to levels between 15000 and $20000(60 \mathrm{~kg}$ bags), as compared to peak production of more than 250 000 bags in the early 90s, this is according to statics from the International Coffee Organization 2010. As Zimbabwean coffee growers struggle, elsewhere e the industry is booming thus the country is losing. There is need to revive the coffee industry for it accounted greatly to Zimbabwe's GDP. With the rise of International Coffee prices to $\$ 3$ per pound from $\$ 1$ per pound in the 90 s. Coffee production and sales if properly revived can bring \$200 million a year.

Most farmers lack cash reserves to support themselves and continue producing they only think of inorganic fertilizers hence need for research on the type of manure and application level which will result in the best seedlings which will establish well in the field and complete the first step in reviving the coffee industry in Zimbabwe. Also lack or limited knowledge on the profitability on organic market and certification potential. The coffee organic market is growing at a faster rate with high demands for organic coffee on markets of Europe, Japan and USA. With respect to increased production costs instead of farmers abandoning their coffee farms they should opt for organic farming and for them to benefit they need to be certified for their systems according to applicable organic production standards. Most Zimbabwean farmers can benefit if they are well equipped with knowledge on organic farming benefits. Since most of the small holder farmers have very small area under coffee production ranging from 0.25 ha to 3 ha they can go for organic fertilizers without much problems.

\subsection{Coffee requirements}

Coffee like any other crop it requires ideal conditions for it to germinate, grow vegetative until it reaches the reproductive stage. 


\subsubsection{Nutritional requirements}

Fertilizers required in the growing medium, $5 \mathrm{Kg}$ Super-phosphate for every $\mathrm{m}^{3}$ of growing mixture, $1 \mathrm{~kg}$ of Rock phosphate and additional micronutrients per every $\mathrm{m}^{3}$ of growing mixture and $1 \mathrm{~kg}$ of $\mathrm{KCl}$ per every $\mathrm{m}^{3}$ growing mixture. Foliar spraying with a $0.3 \%$ blend of $0.5 \mathrm{~B}, 2.2$ $\mathrm{Mg}, 7 \mathrm{Zn}$ and $10 \mathrm{~N}$ after emergency at a two leaf stage. When using manure growth media can be prepared by mixing 70\% soil and 30\% manure Source (Montensen 1999). Young coffee thus from seedling stage to first year require a lot of phosphorous to enhance root growth and quality development.

Nitrogen is one of the most important macronutrients, it is used for functions like photosynthesis and formation of new tissues (Carelli et al 2006).

\subsubsection{Climatic and soil requirements}

Coffee (Arabica coffee) has two sets of climatic conditions in which it can do well. The first set of climatic conditions is the subtropical region, at high altitudes of 16 to $24^{\circ}$, with well-defined rainy and dry season and an altitude of between 1800 to 3600 feet. Optimum temperatures between 15 to $24^{\circ} \mathrm{C}$ year and above these temperatures rate of photosynthesis goes down. Also if temperatures drop to down to $0^{\circ} \mathrm{C}$ there will be high chances that frost damage will occur. These conditions result in only one growing season and one maturation season of coffee, in the coldest part the of autumn. Zimbabwe, Mexico, Jamaica and some Brazilian regions have this climate type. The second set of climatic conditions is in the equatorial region, at altitudes of 3600 to 6300 feet and latitudes which are below $10^{\circ}$. In these areas there is frequent rainfall which result in flowering which is continuous, thus resulting in two harvesting seasons for coffee. Rainy periods determine time for main harvesting. This is typical of the climate in Kenya, Ethiopia and Colombia.

Coffee production has been marked as a success in many parts of the world with different soil types. How-ever the ideal soil type is sandy loam and literally coffee can do well in any fertile soil if the climatic conditions are conducive. In sandy soils or in clayey soils the soil clay content should range between $15 \%$ to 35\% with an optimum ph of 5 to 6 however it can stil be grown in neutral soils and cannot thrive in acidic soils for they produce poor quality coffee with high caffeine content. In-order to attain high yields coffee tree requires soils which are deep and permeable with enough organic matter (Department of Agriculture Forestry and Fisheries 2012). According to (Larcher,2003; Snoeck and Lambot 2009) coffee does well slightly acidic to neutral 
thus (ph 4-7) soils, ph determines soils ability to release nutrients thus it determines the availability of nutrients to plants, also organic matter content and the texture of soil affect nutrient uptake by plants.

\subsection{Manure}

Generally, manure is a cheap source of nutrients which can substitute inorganic fertilizers in gardens, nurseries and fields. Animal manure is often overlooked by people and farmers who are producing animals at a small scale which is resulting in them losing their potential nutrient banks. Manure from animals and composts manure have been used in agriculture for a long time as a soil amendment strategy in-order to maintain soil functions. Fertility of the soil is enhanced by manure by addition of organic matter and nutrients such as nitrogen which will be trapped by soil bacteria (Boller and Hani, 2004).

Organic manure releases nutrients slowly thus it ensures availability of nutrients for longer to the crop. Research done at the university of Alaska Fairbanks showed that manure lose approximately one-third of its nutrients and organic matter value in three months and the other half in six months or even longer unlike inorganic fertilizers which provide nutrients at once thus they are easily exhausted. Manure from animal sources differ in nutrient composition in relation to the type of feed given to the animals. Storage of the manure is of great importance as far as nutrient loss is concerned, during composting manure should be kept shades and water tight bottom especially when it is raining for the nutrients will be washed away making the manure of less importance to crop growth .Also before application the manures need to be composted in-order to destroy weeds since most animals goats cattle, sheep and horses are grazers the dung may contain high levels of weed seeds hence composting will ensure destruction of the weed seeds leaving none or a few viable seeds. There is evidence that manure can increase ph of acidic soils (Whalen et al 2006). Soil enhancing benefits from manures are related to the organic matter that improves soil structure, moisture retention and increase mobility of phosphorous, potassium and other micro nutrients and also stimulate microbial activity (Maerere et al 2001 and Garg and Bahla 2008). Under organic management the ph of soil is increased and the concentrations of plant available nutrients is increased, also total active microbial populations are increased (Dinesh et al., 2000; Lee, 2010).

Most farmers no-longer pay attention to manure as they focus on inorganic fertilizers whose returns are high per $\mathrm{kg}$ application, of-which most of the small holder farmers in the sub Saharan 
regions do not afford hence they just sit back and cease production when there are cheap sources of nutrients which can be used in place of the high costing inorganic fertilizers. Manures are applied in large quantities compared to inorganic fertilizers to give strong residual effect on growth of successive crop (Shiyam et al 2016). Farmers also have interest in the high returns of inorganic fertilizers without considering their impacts like increased erosion due to loss of soil structure resulting in losses of tons of soils per hectare. Use of manure is giving rise to the new farming system of organic farming to avoid use of chemical and synthetic fertilizers which is more environmentally and consumer friendly. Environmental influence on human health encourage growers to convert to organic farming (Fayed 2005). Replacing inorganic fertilizer with organic manure reduces the impact of environmental pollution and there will be minimum accumulation

of organic wastes. Aside from organic manure containing a relatively low nutrient status its benefits are more than those of inorganic (synthetic) fertilizers. Benefits of using organic fertilizers will be observed over long periods unlike benefits of chemical fertilizers which are observed over short periods. Nutrient efficiency with high economic benefits of using organic fertilizers are usually obtained and observed when appropriate application rates are used. Therefore, this study was done in-order to investigate on the effects of different levels of poultry, cattle, goat and sheep manure on coffee seedlings in the nursery.

\subsubsection{Poultry manure}

Poultry manure contains almost all the 13 essential nutrients needed by plants for their growth and development. The nutrients are nitrogen $(\mathrm{N})$, phosphorous $(\mathrm{P})$, potassium $(\mathrm{K})$, calcium $(\mathrm{Ca})$, magnesium $(\mathrm{Mg})$, sulfur $(\mathrm{S})$, manganese $(\mathrm{Mn})$, copper $(\mathrm{Cu})$, zinc $(\mathrm{Zn})$, chlorine $(\mathrm{Cl})$, boron $(\mathrm{B})$, iron (Fe), and molybdenum (Mo). These nutrient's origin maybe be medications, feed and other supplements thereby using PM all the nutrients mentioned above may be made available to the plant (Chastain et al). Poultry manure should be applied into the field as close to planting as possible or soon after application the manure must be in-cooperated into the soil so as to reduce the rate of volatilization (Rasnake et al 2000)

Poultry manure (PM) is an excellent organic fertilizer because it contains high N, P, K and other essential; nutrients (Farhad et al 2009). PM is referred to as a peculiar organic waste, this is because poultry droppings contain a combination of urine and the solid excreta thus no nitrogen and uric acids are lost through urine (Anand and Geeta 2004). Poultry droppings have a high carbon to 
nitrogen ratio making them an excellent organic fertilizer, also PM is very rich in phosphorous and potash which are essential for plant growth (Anand and Geeta 2004). PM was reported to supply phosphorous more readily to plants as compared to other organic nutrient sources (Garg and Bahla 2008), (Ano and Agwu 2006, Uwah et al 2011 and Uwah et al 2014) reported that PM increased soil ph ,organic matter content and soil bulk density. PM application resulted in an increase in soil $\mathrm{N}$ level by 53\%, whereas exchangeable cation increased (Boateng et al 2006). Fertilization with PM increased productivity, size, tubers standard rate in an experiment done on Influence of organic manure on the vegetative growth and tuber production of potato in Sahara Desert region.

In Zimbabwe poultry manure is very abundant since most small holder farmers keep birds on farms and also people at large rear chickens for sale for the business has become viable thus the manure is not scarce. How-ever the nutrient composition is determined by the type of feed and availability of bedding. Despite poultry manure having a high level of nitrogen, availability of nitrogen from poultry manure to plants is the very limited. This is because approximately one third of the nitrogen in PM is in the ammonium form with the other two thirds existing as organic nitrogen. Thus the amount of nitrogen available is ammonium and some which would have been mineralized as microbes degrade the manure (Alabama cooperative extension systems 1999). The disadvantage associated with use of poultry manure is the heavy odors due to high content of urea. In PM the fraction of potassium and phosphorous is considered to be approximately $75 \%$ as effective as other commercial fertilizers during first year of application (Alabama cooperative extension systems 1999).

\subsubsection{Cattle manure}

Cattle manure is an important source of nitrogen for crop production in the small holder sector, it helps farmers to reduce production cost therefore increasing profit margin of the farmer. Nutrients contained in cattle manure are released more slowly and are stored for longer thus supporting better root development leading to higher crop yields. According to the University of Alaska Fair Banks a 1000-pound cow produces 15 tons of manure per year , 15 tons contains an equivalent of 213 pounds of nitrogen, 192 pounds of phosphate $\left(\mathrm{P}_{2} \mathrm{O}_{5}\right)$ and 267 pounds of potassium $\left(\mathrm{K}_{2} \mathrm{O}\right)$ these values are based on the type of feed given to the animal. CM has the following composition $70 \%$ moisture, $20 \%$ organic matter and $3 \%$ mineral matter (containing micro and macro nutrients. The 
carbon to nitrogen ratio is high thus it is used as a bulk material in crop residue recycling (Anand and Geeta 2004). CM has no profusion of bad odors.

\subsubsection{Goat manure}

Goat manure is highly rich in nitrogen compared to horse and cattle manures according to a study carried out at Ohio State University Extension on average goat manure had 22 pounds of nitrogen per ton whereas cattle manure had 10 pounds of nitrogen per ton, hence cattle manure contains half the nitrogen which is contained by goat manure. Goat manure improves soil texture so it improves water use efficiency and allows more nitrogen to reach the plant. Goat manure is dry which makes it produce less odors and also goat manure composts faster. Goat manure decomposes quickly due to its large surface area which is attributed by goat droppings being small in size. Fresh goat manure can contain pathogens in some cases which can make people sick. Therefore, it is always advisable to use composted GM especially for plants which are edible. When using rotted GM instead of composted it manure, the manure must be applied 90 to 120 days before the crop harvesting.

\subsubsection{Sheep manure}

Some of the advantages of sheep manure are that naturally it is a slow nitrogen release fertilizer hence can be used as an organic mulch in vegetable gardens flower beds, seedlings and other crops. Sheep manure has low nitrogen content with high phosphorous and potassium level which are ideal for plant growth. Also sheep manure does not have bad odors. According to (Shufu and Huainii 2004) sheep manure application improves soil properties through improving physiochemical and biological conditions of the soil and increase in organic matter leads to increase in soil cation exchange capacity and soil nutrient retention is increased. The size of sheep droppings provides a large surface area which in-turn enhance microbial activity resulting in quick decomposition of droppings into plant accessible nutrients with a nitrogen content of up-to 2.75\%(Anand and Geeta 2004).

SM because its natural product that does not guarantee it being safe for use. Well composted SM must be used since fresh manure may contain some pathogens which are harmful to humans. Also an excess of the manure can result in land and water (above ground and underground water sources) pollution due to these negative effects use on very steep slopes must be avoided especially during heavy rains. 


\section{CHAPTER THREE}

\section{MATERIELS AND METHODS}

\subsection{Site description}

The trial was conducted in the nursery at Coffee Research Institute, Chipinge, latitude $20^{\circ} 12^{\text {' South }}$ and longitude $32^{\circ} 37^{\prime}$ 'East at an altitude of 1100 above sea level. Mean maximum temperature is $20^{\circ} \mathrm{C}$ and mean minimum temperature is $14^{\circ} \mathrm{C}$. Rainfall range from 800 to $1300 \mathrm{~mm}$ per annum. The soils at Coffee Research Institute are orthoferallitic according to the Zimbabwe Classification System, derived from Umkondo Quartzite's shales and consist of deep, fine-to-medium grained sandy loams on the surface (Chemura et al 2013).

\subsection{Experimental design}

The experiment was laid out in a 3 x 4 Factorial experiment in a Completely Randomised Design (factor 1. organic fertilisers factor 2. application levels). The experiment had 14 experimental plots and 6 pots on each plot replicated 3 times. Different levels of organic manures were compared with the standard which was treated with soil and compound s (6-17-6) and control which had soil only.

\subsection{Treatments and description}

Table 3.2 bellow shows the treatment combinations and description of treatments which were used in this experiment.

Table 3.2: Treatment combinations of different manures and different levels used

\begin{tabular}{|l|l|}
\hline Treatment & Description \\
\hline Poultry & $100 \mathrm{~g} / \mathrm{pot}$ \\
& $250 \mathrm{~g} / \mathrm{pot}$ \\
& $500 \mathrm{~g} / \mathrm{pot}$ \\
Cattle & $100 \mathrm{~g} / \mathrm{pot}$ \\
& $250 \mathrm{~g} / \mathrm{pot}$ \\
\hline
\end{tabular}




\begin{tabular}{|l|l|}
\hline Goat & $500 \mathrm{~g} / \mathrm{pot}$ \\
& $100 \mathrm{~g} / \mathrm{pot}$ \\
& $250 \mathrm{~g} / \mathrm{pot}$ \\
& $500 \mathrm{~g} / \mathrm{pot}$ \\
& $100 \mathrm{~g} / \mathrm{pot}$ \\
& $250 \mathrm{~g} / \mathrm{pot}$ \\
Sheep & $500 \mathrm{~g} / \mathrm{pot}$ \\
Standard & Compound $\mathrm{S}\left(3 \mathrm{~kg} / \mathrm{m}^{3}\right.$ of soil $)$ \\
Control & Soil only \\
\hline
\end{tabular}

\subsection{Sources of organic fertilizers and soil}

The organic fertilisers were obtained from farmers around Coffee Research Institute and it was one-year-old manure which farmers had stocked for use in their fields. Top soil was collected from a nearby fallow land which has been undisturbed for several years

\subsection{Preparation of the potting media}

Wet manure was sun dried and sifted using a $5 \mathrm{~mm}$ sieve. Soil was sieved using a $5 \mathrm{~mm}$ sieve and then thoroughly mixed with sifted manure at different soil to manure levels. The mixed soil and manure were placed in black polythene bags (pots)measuring $12 \mathrm{~cm}$ diameter and $25 \mathrm{~cm}$ height. The standard media was prepared by mixing sifted soil with compound $\mathrm{S}$ and control had soil only. The pots were laid in the nursery and irrigated daily for four days before transplanting.

\subsection{Selection of seedlings}

Seedlings of Catmor 129 with a uniform number of leaves and of the same height were selected (pricked)from the seed bed and transplanted into polythene bags with the prepared growth media. 


\subsubsection{Agronomic procedure}

\subsubsection{Irrigation}

Irrigation was done to field capacity. Water was applied using a horse pipe or watering cans and evenly distributed.

\subsubsection{Weeding}

Hand weeding was done each time a weed was spotted in -order to keep the pots free from any weeds.

\subsubsection{Pest and diseases control}

No fungicides or pesticides were used in the experimental plots. Pest as vectors of disease and also insect pests were managed by controlling them around the nursery and in other seedlings using chemicals so as to prevent dissemination into the experimental plots.

\subsection{Data collection and Measurements}

Data was collected forty nightly for 3 months. Height was measured using a meter rule from the soil surface to the tip of the apical meristem. Number of leaves by counting the unfolded leaves, girth was measured at $4 \mathrm{~cm}$ from the soil surface using a Veneer Calliper. The seedlings are carefully excavated and cleaned with tap water and root length is measured. Dry matter of (aerial and underground parts) was measured using a digital balance after oven drying for 8 hours at $70^{\circ} \mathrm{c}$. 


\section{CHAPTER FOUR}

\section{RESULTS}

\subsection{Effects of different fertilizer levels on coffee seedlings}

An interaction was observed $(\mathrm{p}<0.05)$ between fertilizer application level and the fertilizer type with respect to stem height. There were no significant differences between the fertilizer types at an application level of $100 \mathrm{~g}$ however at an application level of $250 \mathrm{~g}$ a significant difference was observed among all fertilizer types except sheep and goat manures which had no significant difference. At an application level of $500 \mathrm{~g}$ cattle manure was significantly different to poultry, goat and sheep manure whilst poultry, goat and sheep manure showed no significant difference at an application of $500 \mathrm{~g}$. Compound S produced the tallest seedlings compared to other fertilizers and the untreated soil. All fertilizers produced plants which were taller than the those from the control (untreated soil). Figure 4.1 below shows the results presented above.

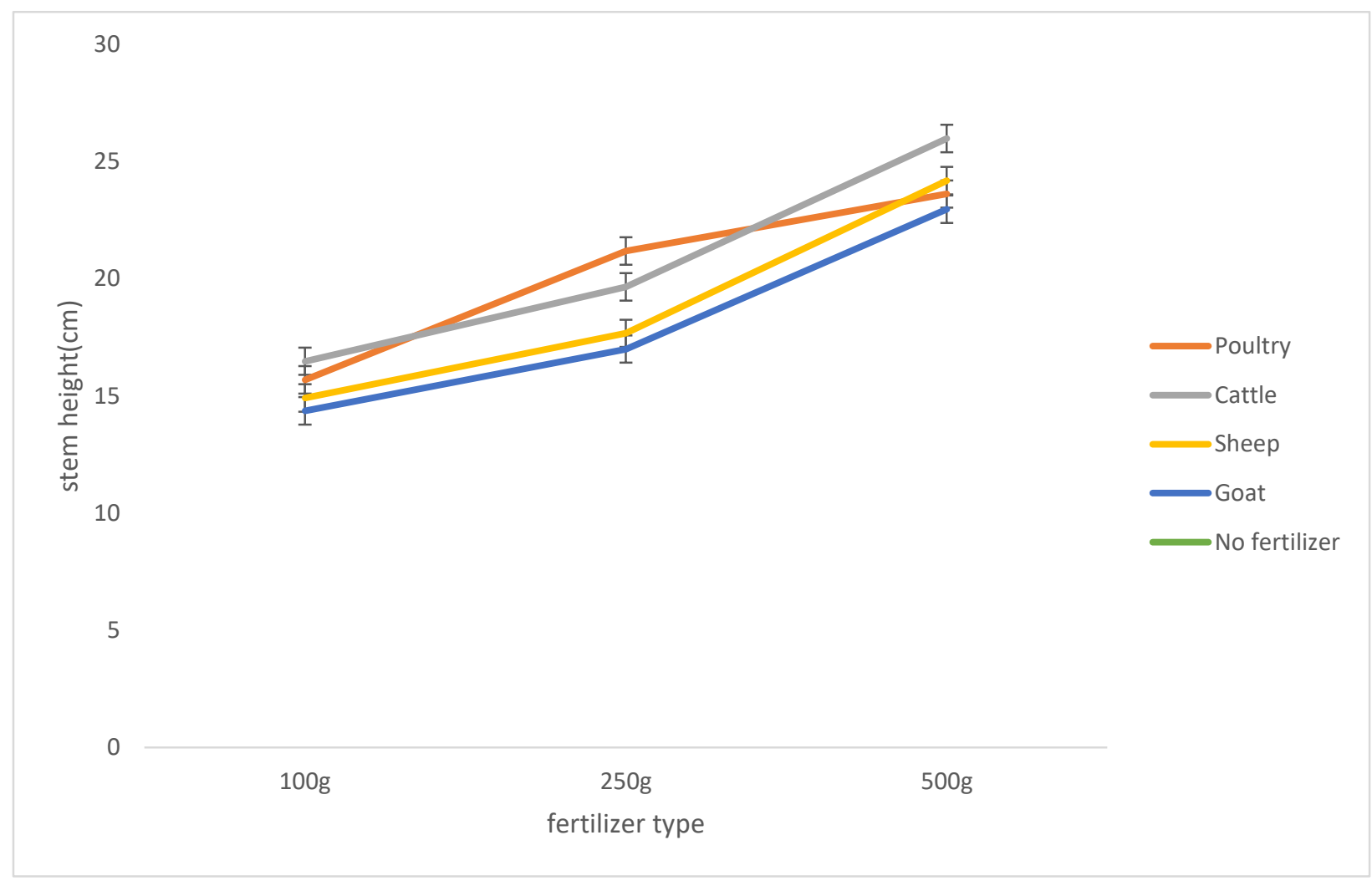

Figure 4.1 Effects of different fertilizer levels on stem height of coffee seedlings 


\subsection{Effects of different fertilizer levels on stem girth of coffee seedlings}

There was interaction between the application level and the type of fertilizer $p<0.05$. Poultry manure was significantly different to cattle, goat and sheep manure at $100 \mathrm{~g}$ and $250 \mathrm{~g}$ however at $500 \mathrm{~g}$ poultry and goat manure were not significantly different this is clearly illustrated in figure 4.2 below. Compound $\mathrm{S}$ had significantly higher stem girth than all organic fertilizers at an application level of $100 \mathrm{~g}$. At $250 \mathrm{~g}$ and $500 \mathrm{~g}$ all organic fertilizers had significantly higher stem girth as compared to compound S. Untreated soil had the least stem girth thus there was a significant difference $\mathrm{p}<0.05$ compared with all organic fertilizers at all application levels.

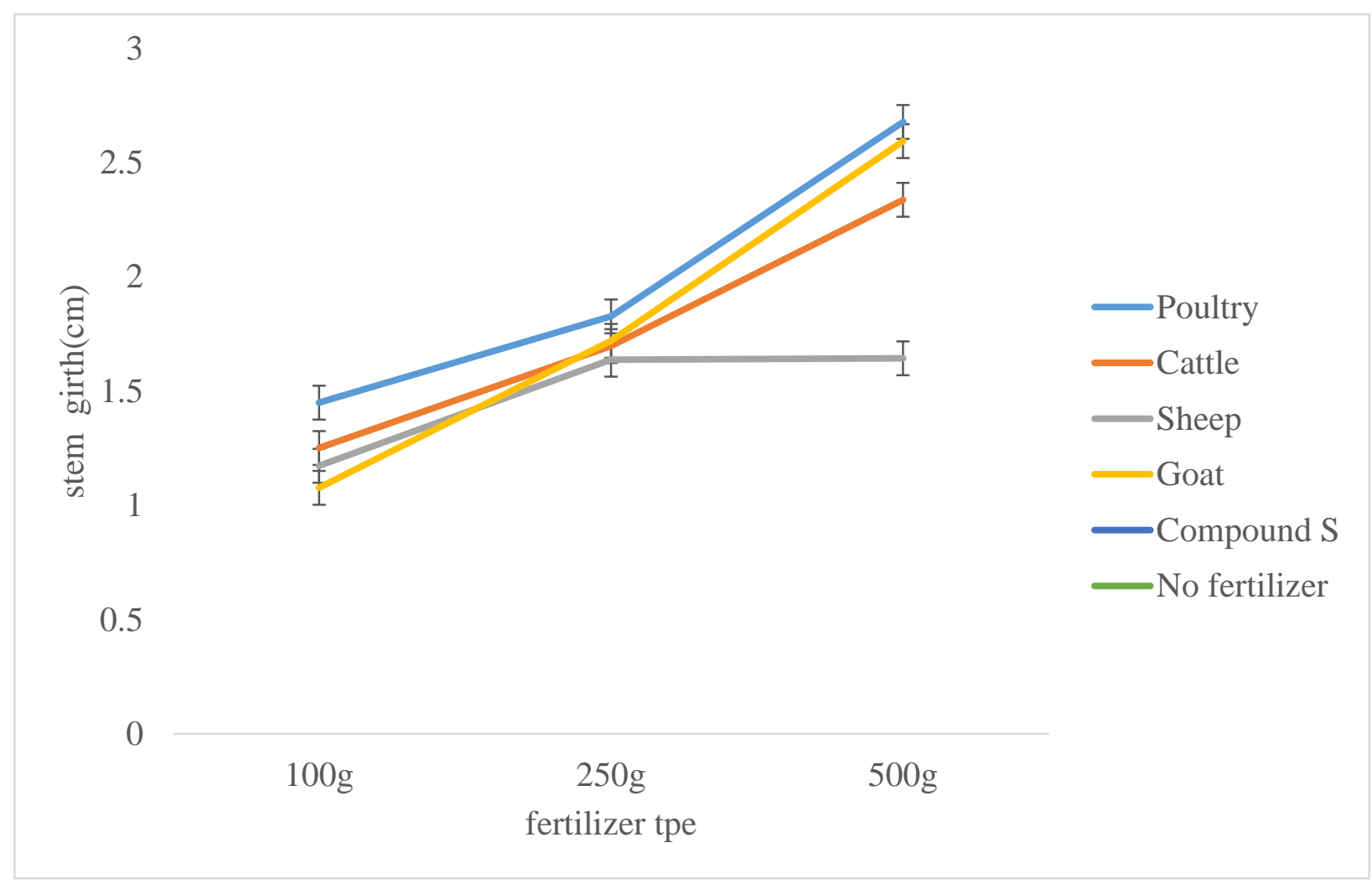

Figure 4.2 Effects of different fertilizer levels on stem girth of coffee seedlings

\subsection{Effects of different fertilizer levels on number of leaves in coffee seedlings}

There was an interaction between fertilizer application level and the type of fertilizer $(p<0.05)$. An increase in the level of application of all organic fertilizers resulted in an increase in the number of leaves of the coffee seedlings. There was a significant difference between compound $\mathrm{S}$ and the organic fertilizers at an application rate of $100 \mathrm{~g}$ with compound $\mathrm{S}$ having more number of leaves than the organic fertilizers. At an application level of $250 \mathrm{~g}$ compound $\mathrm{S}$ had a higher number of 
leaves than cattle, goat, sheep manure and at the same application level poultry had more number of leaves compare to compound $\mathrm{S}$ this is shown in figure 4.3 below. At an application rate of $100 \mathrm{~g}$ there was no significant difference between poultry and cattle but a significant difference was observed between poultry and sheep and also between poultry and goat manure. The control (untreated soil had the least number of leaves compared with all organic fertilizers at all application levels.

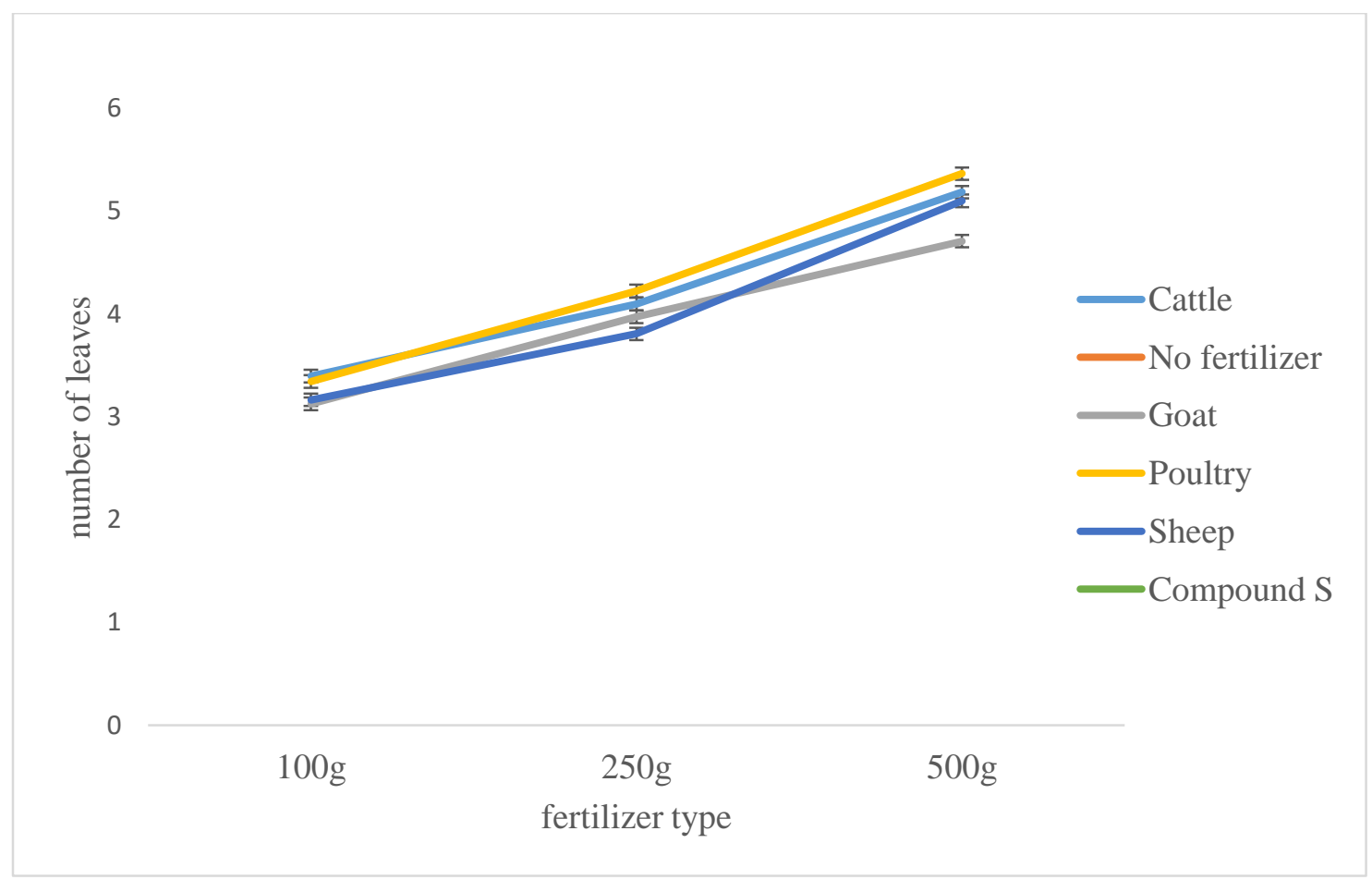

Figure 4.3 Effects of different fertilizer levels on number of leaves of coffee seedlings

\subsection{Effects of different fertilizer levels on number of leaves in coffee seedlings}

There was an interaction between fertilizer application level and type of fertilizer $p<0.05$. At an application level of 100g all organic fertilizers had shorter roots as compared to those of seedlings treated with compound S. At an application level of $250 \mathrm{~g}$ poultry and cattle manure exceeded compound $\mathrm{S}$ and goat and sheep manure were out performed by compound $\mathrm{S}$ in root length of coffee seedlings. How-ever at an application rate of $500 \mathrm{~g}$ all organic fertilizers had longer roots as compared to those of seedlings treated with compound S. The untreated soil had the shortest roots compared to all organic fertilizers at the 3 application levels. The gradient for effects of poultry manure on root length at all levels is steep this is clear in figure 4.4. 


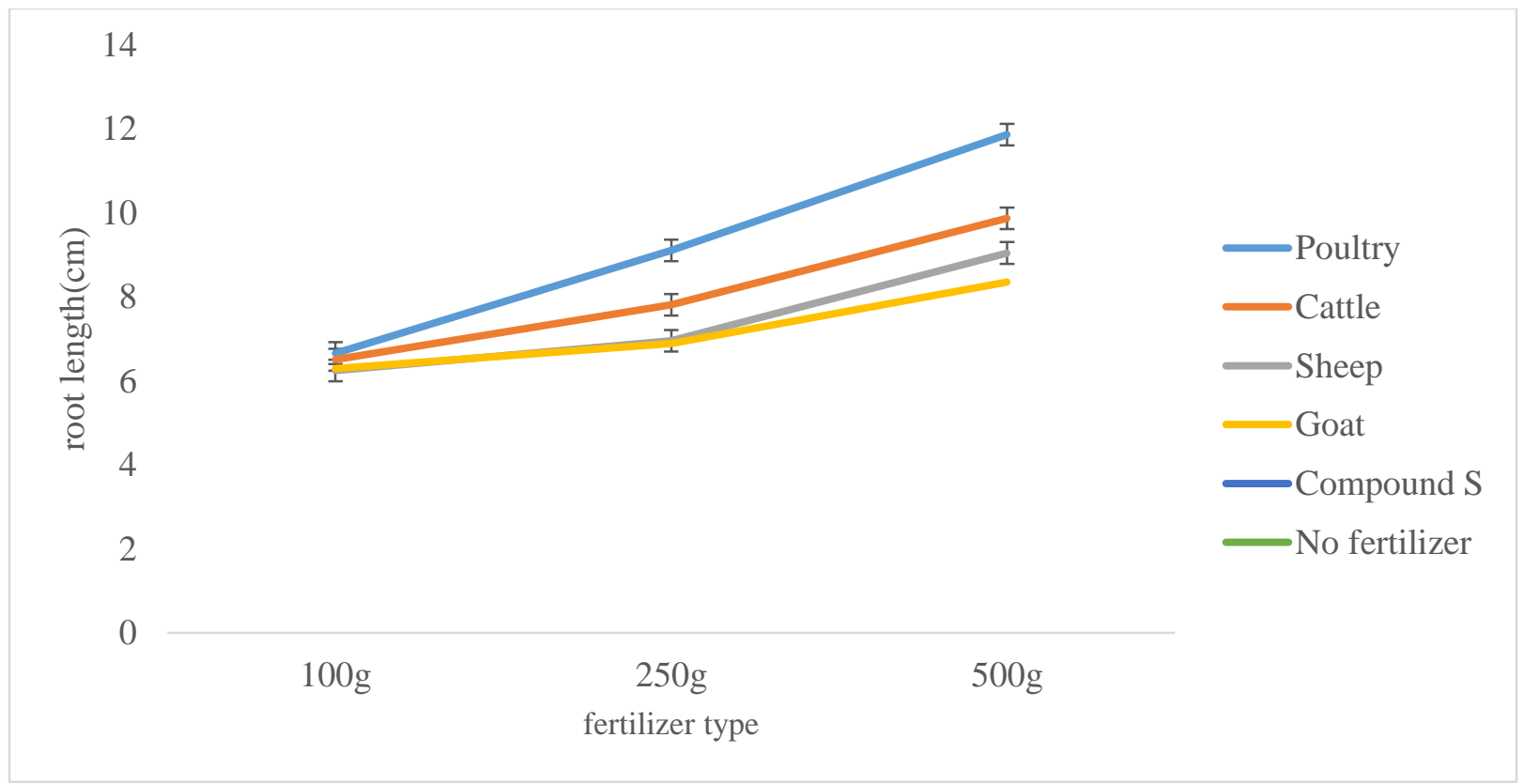

Figure 4.4 Effects of different fertilizer levels on root length of coffee seedlings

\subsection{Effects of different fertilizer levels on dry matter accumulation in coffee seedlings}

There was an interaction between fertilizer application level and type of fertilizer $\mathrm{p}<0.05$. Poultry manure was significantly different from cattle, goat and sheep manure at all application levels. At an application level of $100 \mathrm{~g}$ there was no significant difference among cattle, goat and sheep manure. At an application level of $250 \mathrm{~g}$ there was no significant difference among the three manures cattle, goat and sheep. At an application level of $500 \mathrm{~g}$ cattle and sheep manure were not significantly different however cattle manure was significantly different from goat manure in respect with dry matter accumulation. At an application level of $100 \mathrm{~g}$ all organic fertilizers had less dry matter accumulation compared with compound S. 


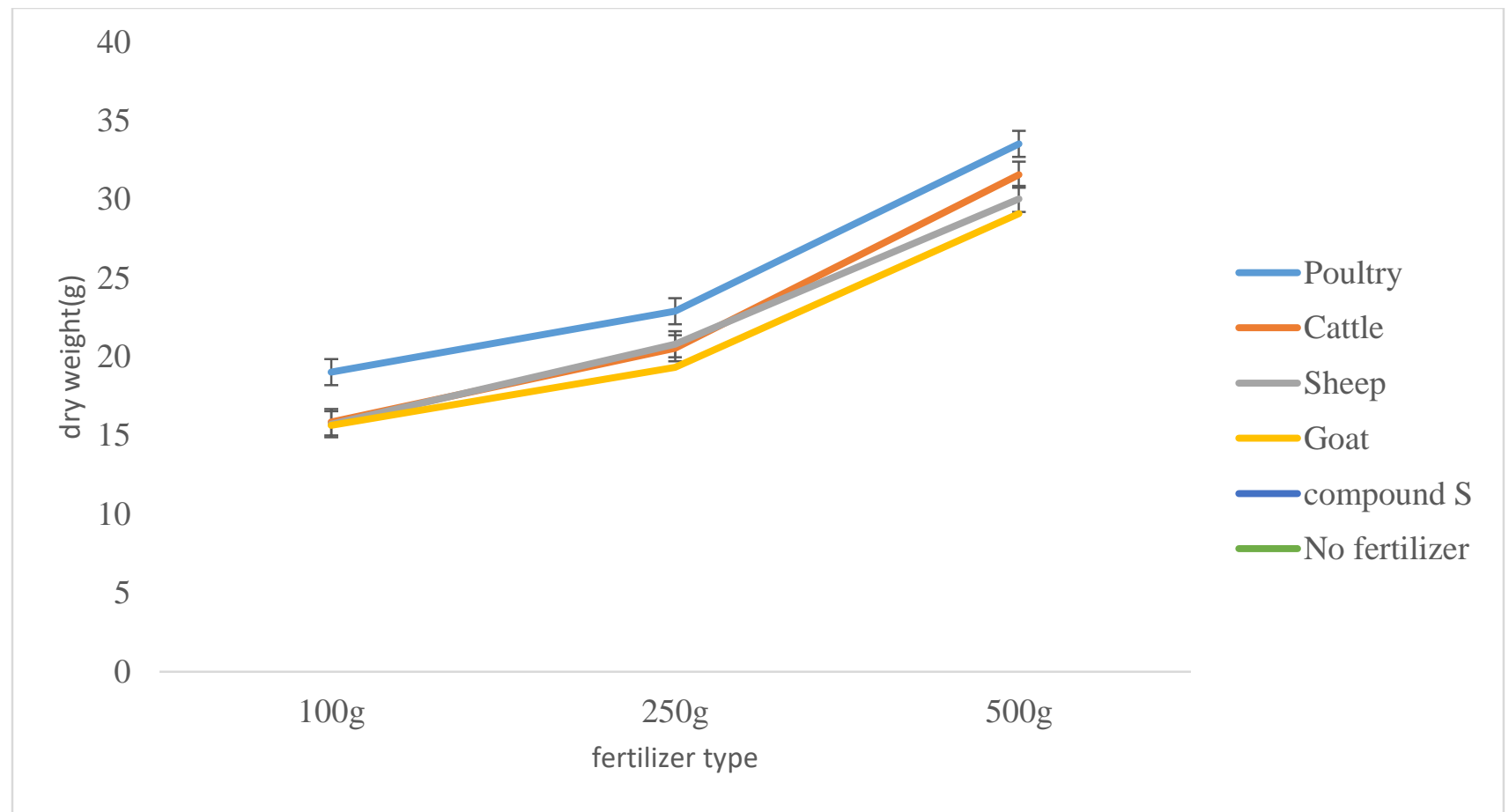

Figure 4.5 Effects of fertilizer levels on dry matter accumulation in coffee seedlings. 


\section{CHAPTER FIVE}

\section{RESULTS AND DISCUSION}

\subsection{Effects of different fertilizer application levels on stem length of coffee seedlings}

Compound $\mathrm{S}$ gave higher significant difference compared with organic fertilizers in their three levels of application which were used in this experiment on stem height. This can be due to the fact that synthetic fertilizers are predominantly soluble and thus they are immediately available to the plant. Increase in poultry manure from $250 \mathrm{~g}$ to $500 \mathrm{~g}$ did not result in increased growth, this can be as a result of harmful effects of poultry manure which can be as a result from an increase in electrical conductivity in the soil at high application levels. Also height did not increase significantly with increase in application of poultry manure maybe due to the fact that, poultry manure had a lot of phosphorous content. This could have resulted in excess amount of phosphorous binding to other elements including nitrogen which was responsible for stem elongation (Samuel et al 2003). Use of organic fertilizers reduce deleterious effects posed by use of chemical fertilizers. Continuous use of chemical fertilizers can also lead to accumulation of heavy metals in the tissues of a plant which will in-turn compromise fruit quality (Shimbo et al.,2001). How-ever it was reported that the supply of nitrogen (available nitrogen to the plant) from organic fertilizers is low. This can be as a result of slow rate of mineralization thus plant height and yield are low in plants treated with organic fertilizers as compared to those treated with synthetic fertilizers (Lee,2010). Unfertilized soil had seedlings with the least height this was as a result of low nitrogen levels in the soil which was used in the experiment.

\subsection{Effects of different fertilizer application levels on stem girth of coffee seedlings}

There was interaction between and the type of fertilizer $\mathrm{p}<0.05$ in respect with coffee seedlings stem girth. Poultry manure was significantly different to cattle, goat and sheep manure at $100 \mathrm{~g}$ and $250 \mathrm{~g}$. How-ever at $500 \mathrm{~g}$ poultry and goat manure were not significantly different despite poultry manure having more nutrients. Samuel et al 2003 found that goat manure increased ph and nitrogen level this could be the reason why goat manure at $500 \mathrm{~g}$ resulted in high stem girth. Compound $\mathrm{S}$ had significantly higher stem girth than all organic fertilizers at an application level of $100 \mathrm{~g}$ because amount of nutrients in $100 \mathrm{~g}$ of manure was little compared to compound S. At $250 \mathrm{~g}$ and $500 \mathrm{~g}$ organic fertilizers had significantly higher stem girth as compared to soil had the least stem girth thus there was a significant difference $\mathrm{p}<0.05$ compared with all organic fertilizers at all 
application levels. This was attributed by soil having a low inherent fertility thus it could not supply seedlings with the nutrients they required.

\subsection{Effects of different fertilizer application levels on number of leaves of coffee seedlings}

There was an interaction between fertilizer application level and the type of fertilizer $(\mathrm{p}<0.05)$. An increase in the level of application of all organic fertilizers resulted in an increase in the number of leaves of the coffee seedlings. There was a significant difference between compound $\mathrm{S}$ and the organic fertilizers at an application rate of $100 \mathrm{~g}$ with compound $\mathrm{S}$ having more number of leaves than the organic fertilizers. At an application level of $250 \mathrm{~g}$ compound $\mathrm{S}$ had a higher number of leaves than cattle, goat, sheep manure and at the same application level poultry had more number of leaves compare to compound S. This goes in line with (Ndubuaku et al 2014) who observed that poultry manure increased the nutrient status of the soil and there-by boosting crop productivity. In this experiment an increase in number of leaves would result in increased rate of photosynthesis thus increasing assimilates production which will in-turn result in high dry matter accumulation. In an experiment done on effects of organic fertilizers on potting media for moringa poultry manure was also concluded to be the best fertilizer to add in growth media.

At an application rate of $100 \mathrm{~g}$ there was no significant difference between poultry and cattle but a significant difference was observed between poultry and sheep and also between poultry and goat manure. The control (unfertilized soil had the least number of leaves compared with all organic fertilizers at all application levels.

\subsection{Effects of different fertilizer application levels on root length of coffee seedlings}

There was an interaction between fertilizer application level and type of fertilizer $\mathrm{p}<0.05$. At an application level of $100 \mathrm{~g}$ all organic fertilizers had shorter roots as compared to those of seedlings treated with compound S. This was because nutrients in $100 \mathrm{~g}$ of organic fertilizers was not sufficient to support mass root development. At an application level of $250 \mathrm{~g}$ poultry and cattle manure exceeded compound S, this was also observed by (Maerere et al.,2001) that soil phosphorous and nitrogen content increase with increasing rate of poultry, goat and cattle manure. Goat and sheep manure were out performed by compound $\mathrm{S}$ in root length of coffee seedlings at $250 \mathrm{~g}$. How-ever at an application rate of $500 \mathrm{~g}$ all organic fertilizers had longer roots as compared to those of seedlings treated with compound S. The untreated soil had the shortest roots compared 
to all organic fertilizers at the 3 application levels this showed that addition of organic fertilizers even in low quantities an enhance growth as compared to unfertilized soil.

\subsection{Effects of different fertilizer application levels on dry matter accumulation in coffee seedlings}

There was an interaction between fertilizer application level and type of fertilizer $\mathrm{p}<0.05$. Poultry manure was significantly different from cattle, goat and sheep manure at all application levels. At an application level of $100 \mathrm{~g}$ there was no significant difference among cattle, goat and sheep manure. Poultry manure recorded the highest dry matter accumulation in coffee seedlings. It was observed that poultry manure increased soil nutrient status and improved productivity (Ndubuaku et al 2014). PM is an excellent fertilizer for it contains N,P,K and also other essential nutrients (Farhad et al.,2009) this could have been the reason why poultry manure had high dry matter accumulation in coffee seedlings. PM has been reported to be able to supply phosphorous more readily than other organic sources (Garg and Bahla ,2008) this was observed in the experiment for poultry manure exceeded other organic manures in respect with dry matter accumulation. At an application level of $250 \mathrm{~g}$ there was no significant difference among the three manures cattle, goat and sheep. At an application level of $500 \mathrm{~g}$ cattle and sheep manure were not significantly different however cattle manure was significantly different from goat manure in respect with dry matter accumulation. At an application level of $100 \mathrm{~g}$ all organic fertilizers had less dry matter accumulation compared with compound S. Unfertilized soil had the least dry matter accumulation due to low inherent fertility of the soil. 


\section{CHAPTER SIX}

\subsection{CONCLUSION}

The study showed that application of poultry manure at $250 \mathrm{~g}$ and $500 \mathrm{~g}$ resulted in high stem girth, higher leaf number, longer roots and more dry matter accumulation as compared to the common practice of using compound S.

There was an interaction between application level and type of fertilizer $\mathrm{p}<0.05$ on height, stem girth, number of leaves, root length and dry matter accumulation in coffee seedlings in the nursery.

Overall poultry manure at $250 \mathrm{~g}$ and $500 \mathrm{~g}$ performed better than compound $\mathrm{S}$ except in stem height. Also cattle manure at an application level of 500g performed better than compound $\mathrm{S}$ in all growth parameters which were measured except in height.

Goat and sheep manure at all application levels performed better than untreated soil.

\subsection{RECOMMENDATIONS}

Basing on the results of this research it is recommended that farmers use poultry manure at $500 \mathrm{~g}$, when producing coffee seedlings. This recommendation collaborates with the fact that synthetic fertilizers are expensive for poor farmers to afford.

In the absence of compound S, poultry or cattle manure, sheep or goat manure can be used as a source of nutrients at $500 \mathrm{~g}$ per pot because its performance was better than that of untreated soil.

It is also recommended that further research is done using levels which are even higher than the $500 \mathrm{~g}$ except for poultry manure on height since an increase in application level did not result in increased stem height. 


\section{REFERENCES}

Alabama Cooperative Extension Systems. (1999). The value and use of poultry manure as fertilizer.

Ano, A. O., \& Agwu, J. A. (2006). Effect of animal manures on selected soil properties: II. Nitrogen, potassium and phosphorus. Nigerian Journal of soil science, 16(1), 145-150.

Boateng, S. A., Zickermann, J. and Kornaharens, M. (2006). Effect of poultry manure on growth and yield of maize. West African Journal Applied Ecology 9:1-11.

Boller, E. \& Hani, F. (2004). Manures and soil amendments: Ideal book on functional biodiversity of the farm level. Biology and Fertility of Soils, 40:2.

Canelli. M.L.C., Fahl J. 1 and Ramalho J. D .C. (2006). Aspects of nitrogen metabolism in coffee plants, Brazilian journal of Plant Physiology $18 ; 19-21$.

Dinesh, R., Dubey, R.P., Ganeshamurthy, A.N. \& Prasad, G.S. (2000). Organic manuring in rice based cropping system: effects on soil microbial biomass and selected enzyme activities. current Science. 79: 1716-1720.

Farhad, W., Saleem, M. F. Cheema, M. A. and Hammad, H. M. (2009). Effect of poultry manure levels on the productivity of spring maize (Zea mays L.). Journal of Animal and Plant Sciences 19(3):122-125.

Fayed, T.A. (2010). Response of four olive cultivars to common organic manures in Libya. American Eurasian J. Agric. \& Environ. Sci., 8 (3): 275-291.

Garg, S. and Bahla, G. S. (2008). Phosphorus availability to maize as influenced by organic manures and fertilizer $\mathrm{P}$ associated phosphatase activity in soils. Bioresource Technology

International Coffee Organization. (2013). Promotion of coffee production in Zimbabwe through establishing nurseries, replanting and capacity building of farmers.

Kimani M., Little T. \& Vos J. G.M. (2002). Introduction to Coffee Management through Discovery Learning, Nairobi, CABI Bioscience. 
Kumar P., Gupta V.K., Misra A.K., Modi D.R., Pandey B.K. (2009) Potential of Molecular Markers in Plant Biotechnology. Plant Omics Journal 2:141-162.

Lee, J. (2010). Effect of application methods of organic fertilizer on growth, soil chemical properties and microbial densities in organic bulb onion production. Scientia Horticulturae. 124: $299-305$.

Maerere, A. P., Kimbi, G. G. and Nonga, D. L. M. (2001). Comparative effectiveness of animal manures on soil chemical properties, yield and root growth of Amaranthus (Amaranthus cruentus L.). African Journal of Science and Technology 1(4):14-21.

Masasi, B. (2015). Impact assessment of the market systems approach for revitalisation of smallholder irrigation schemes in Zimbabwe: case study of Mutema irrigation scheme. MSc. Thesis. UNESCO-IHE.

Rasnake, M., B. Thom, \& F. Sikora. (2000). Using Animal Manures as Nutrient Sources. Cooperative Extension Service, University of Kentucky. http://www2.ca.uky.edu/ agcomm/pubs/agr/agr146/agr146.htm.

Samuel, R. C., Ikpe, F. N. Osakwe, J. A. Tenkoano, A. and Okarter, U. C. (2003). Effect of wood based compost and fertilizer application on the growth and yield of cooking banana hybrid and soil chemical properties in south eastern Nigeria. African Journal of Environmental Studies 4:64-68.

Shimbo, S., Watanabe, T., Zhang, Z.W. \& Ikeda, M. (2001). Cadmium and lead contents in rice and other cereal products in Japan in 1998-2000. Science of the Total Environment. 281: $165-175$.

Shufu, D. and Huairui, S. (2004). Sheep manure improves the nutrient retention capacity of apple orchard soils. Acta Hort. 638: 151-155.

University of Alaska Fair Banks September (2013). www.uaf.edu/ces accessed 09-28-17.

Uwah, D. F., Eneji, A. E. and Eshiet, U. J. (2011). Organic and mineral fertilizers effects on the performance of sweet maize (Zea mays (L.) saccharata Strut) in south eastern rainforest zone of Nigeria. International Journal of Agriculture Sciences 3(1):54-61. 
Uwah, D. F., Ukoha, G. O and Iyango, J. (2012). Okra performance and soil and water conservation as influenced by poultry manure and organic mulch amendments. Journal of Food, Agriculture \& Environment 10(1):748-754.

Whalen J.K; Chang Ch; Clayton C.W. and Carefoot J.P. Research journal's Journal of Commerce, Vol. 1. No. 2: 5. 


\section{APPENDICES}

Appendix 1: ANOVA table for the effects of different fertilizer levels on stem height of coffee seedlings.

\begin{tabular}{lrrrrr|}
\hline Source of variation & d.f. & s.s. & m.s. & v.r. & F pr. \\
rep stratum & 2 & 8.756 & 4.378 & 4.26 & \\
& & & & & \\
rep.*Units* stratum & 5 & 1004.852 & 200.970 & 195.55 & $<.001$ \\
manure_type & 2 & 315.693 & 157.846 & 153.59 & $<.001$ \\
level & 10 & 175.943 & 17.594 & 17.12 & $<.001$ \\
manure_type.level & 34 & 34.942 & 1.028 & & \\
Residual & & & & & \\
& 53 & 1540.187 & & & \\
Total & & & & & \\
\hline
\end{tabular}

Appendix 2: ANOVA table for the effects of different fertilizer levels on stem girth of coffee seedlings.

\begin{tabular}{lrrrrr}
\hline Source of variation & d.f. & s.s. & m.s. & v.r. & F pr. \\
rep stratum & 2 & 0.46183 & 0.23091 & 14.01 & \\
& & & & & \\
rep.*Units* stratum & 5 & 7.68546 & 1.53709 & 93.25 & $<.001$ \\
manure_type & 2 & 4.66834 & 2.33417 & 141.61 & $<.001$ \\
level & 10 & 3.40355 & 0.34036 & 20.65 & $<.001$ \\
manure_type.level & 34 & 0.56044 & 0.01648 & & \\
Residual & & & & & \\
Total & 53 & 16.77961 & & & \\
\hline
\end{tabular}

Appendix 3: ANOVA table for the effects of different fertilizer levels on number of leaves on coffee seedlings.

\begin{tabular}{lcrrrr|}
\hline Source of variation & d.f. & s.s. & m.s. & v.r. & F pr. \\
rep stratum & 2 & 0.45021 & 0.22511 & 20.39 & \\
rep.*Units* stratum & & & & & \\
\end{tabular}




$\begin{array}{lrrrrr}\text { manure_type } & 5 & 13.41299 & 2.68260 & 242.96 & <.001 \\ \text { level } & 2 & 13.52457 & 6.76229 & 612.45 & <.001 \\ \text { manure_type.level } & 10 & 7.09972 & 0.70997 & 64.30 & <.001 \\ \text { Residual } & 34 & 0.37541 & 0.01104 & & \\ & & & & & \\ \text { Total } & 53 & 34.86291 & & & \end{array}$

Appendix 4: ANOVA table for the effects of different fertilizer levels on root length of coffee seedlings.

\begin{tabular}{lcrrrr}
\hline Source of variation & d.f. & s.s. & m.s. & v.r. & F pr. \\
rep stratum & 2 & 0.5774 & 0.2887 & 1.45 & \\
& & & & & \\
rep.*Units* stratum & 5 & 81.5845 & 16.3169 & 81.83 & $<.001$ \\
manure_type & 2 & 45.9221 & 22.9611 & 115.15 & $<.001$ \\
level & 10 & 31.4014 & 3.1401 & 15.75 & $<.001$ \\
manure_type.level & 34 & 6.7798 & 0.1994 & & \\
Residual & & & & & \\
& 53 & 166.2653 & & & \\
Total & & & & & \\
\hline
\end{tabular}

Appendix 5: ANOVA table for the effects of different fertilizer levels on dry matter accumulation in coffee seedlings.

\begin{tabular}{lrrrrr}
\hline Source of variation & d.f. & s.s. & m.s. & v.r. & F pr. \\
rep stratum & 2 & 69.659 & 34.829 & 16.84 & \\
& & & & & \\
rep.*Units* stratum & 5 & 526.902 & 105.380 & 50.96 & $<.001$ \\
manure_type & 2 & 1070.060 & 535.030 & 258.74 & $<.001$ \\
level & 10 & 292.228 & 29.223 & 14.13 & $<.001$ \\
manure_type.level & 34 & 70.306 & 2.068 & & \\
Residual & & & & & \\
& 53 & 2029.154 & & & \\
Total & & & & & \\
\hline
\end{tabular}


